\title{
Investment Opportunities and Audit Report Lags: Initial Evidence
}

\author{
Trung Pham ${ }^{1}$, Mai Dao ${ }^{2} \&$ Veena L. Brown ${ }^{3}$ \\ ${ }^{1}$ Broad College of Business, Michigan State University, Michigan, USA \\ ${ }^{2}$ College of Business and Innovation, University of Toledo, Toledo, USA \\ ${ }^{3}$ Sheldon B. Lubar School of Business, University of Wisconsin-Milwaukee, USA \\ Correspondence: Mai Dao, College of Business and Innovation, University of Toledo, Toledo, Ohio 43606, USA. Tel: \\ 1-419-530-2340. E-mail: mai.dao@utoledo.edu
}

Received: August 21, 2014

Accepted: September 13, 2014

Online Published: September 16, 2014

doi:10.5430/afr.v3n4p45

URL: http://dx.doi.org/10.5430/afr.v3n4p45

\begin{abstract}
We examine the association between audit report lag (ARL) and the level of investment opportunity of U.S. firms. High investment opportunities have been perceived to increase audit risk. External auditors, therefore, have to increase the required scope of audit work, which is expected to lead to longer audit report delays. The paper is motivated by (1) the effect of audit report lag on the timeliness of financial reporting and the market reactions to late earnings releases; and (2) the limited research on investment opportunities. With the sample of 8520 U.S. firm-year observations during the 2010-2012 period, we find firms with high investment opportunities are more likely to have longer audit report lags. Our results extend the contemporary research on ARL and investment opportunities. The paper also provides useful information for firms' management and external auditors.
\end{abstract}

Keywords: Investment opportunities, Audit report lag, External auditors, Audit risk

\section{Introduction}

The objective of this study is to examine whether audit report lag (ARL) is longer for U.S. firms with high investment opportunities (HIO). Prior studies (on both U.S. firms and international firms (such as, Canada, Hong Kong, and Spain) show ARL is associated with various firm-related, auditor-related and other factors (e.g., Ashton, Willingham, \& Elliott, 1987; Newton \& Ashton, 1989; Bamber, Bamber, \& Schoderbek, 1993; Schwartz \& Soo, 1996; Jaggi \& Tsui, 1999; Leventis, Weetman, \& Caramanis, 2005; Ettredge, Li, \& Sun, 2006; Tanyi, Raghunandan, \& Barua, 2010; Habib \& Bhuiyan, 2011). Generally, ARL is related to such firm-related factors as industry classification, the existence of extraordinary items, net income, and material weakness in internal control. ARL is also found to be associated with auditor-related factors including auditor size, auditor type, audit technology, amount of audit work required, and audit effort. While various other factors have been examined, to our knowledge, no prior study has examined whether audit report lag is associated with firms' level of investment opportunities. Investigating the relation between audit report lag and investment opportunities is important because the findings of the study will inform management of HIO firms of one of the consequences of being an HIO firm so that they may take appropriate action to reduce any adverse consequences. The study findings will also benefit external auditors in assessing audit fees and in planning the audit.

The paper is also motivated by the direct effect of audit report delay on the timeliness of financial information to be released to the public. Timely provision of financial information is important to investors since it affects their investment decisions. Prior research documents late earnings releases are negatively viewed by the market because it can "diminish the value of public disclosures relevant to the pricing of securities and create inequality among market participants who do not share similar access to private information" (Schwartz \& Soo, 1996).

Moreover, to our knowledge, there is limited research in investment opportunities. Prior studies mainly investigate the influences of U.S. firms' investment opportunities on management's decision making and behaviors. There has been scant research on other consequences of high investment opportunities. As firms can choose to expand their businesses with diverse growth options, it is necessary that they understand how different growth options impact firms' operations and financial performance. In the current study, we investigate whether growth options/investment opportunities influence the timeliness of financial reporting and ultimately firms' financial performance. 
We use factor analysis to create a composite measure of investment opportunities (i.e., investment opportunity factor) to measure investment opportunities. Using a sample of 8520 U.S. firm-year observations from 2010 to 2012, we find that HIO firms have long audit report delays. The results are consistent with the expectation that U.S. firms with high investment opportunities tend to have greater audit risks resulting from the increase in uncertainty relating to future discretionary investment expenditure, difficulty in observing managers' activities, and weak internal controls.

The current study makes several contributions to the literature. First, this paper extends prior research on audit report lags. Previous studies on audit report lags concentrate on identifying the determinants of audit report lag other than investment opportunities. Our paper furthers this line of research by examining whether audit report lag is associated with investment opportunities. Prior research on investment opportunities mainly focuses on investigating the influence of investment opportunities on managements' behavior and decision making while research on the effect of investment opportunities' on external auditing remains sparse. Second, our paper contributes to the investment opportunity literature by providing direct empirical evidence on the effect of firms' investment opportunities on external auditors' efficiency (as proxied by audit report lag). Third, prior studies on investment opportunities (e.g., Tsui, Jaggi, \& Gul, 2001; Cahan, Godfrey, Hamilton, \& Jeter, 2008) show that audit risks increase for HIO firms due to the increasing uncertainty and unobservability of managers' behaviors, and weak internal control. This results in more work and higher audit fees for auditors. Prior research fails to provide evidence on the timing of audit report issuance. We advance the literature by examining whether the increase in audit risks in HIO firms leads to longer audit report delays.

Our study differs from prior studies involving audit report lags in a number of ways. First, the extant literature on audit report lag provides findings based on evidence using sample years prior to 2008 while our study focuses on the period 2010 to 2012. This period provides a cleaner analysis as it diminishes any potential effects of major economic events that may influence the timeliness of financial reports, for example, the passage of Sarbanes Oxley Act or the recent financial crisis. Second, while previous research examines individual firm characteristics as determinants of audit report lag, our study uses the composite measure that includes several firm characteristics as a measure of investment opportunity.

The remainder of the paper is organized as follows. The next section reviews prior literature and develops our hypothesis. This is followed by the discussions of research method and results. The final section synthesizes our findings and concludes.

\section{Related literature and hypothesis development}

\subsection{Theoretical background: Agency theory and investment opportunities}

According to agency theory, the separation of ownership and control leads to agency conflicts. In the agency relationship, shareholders (the principal) engage and delegate some decision making authority to managers (the agent). However, each party is a utility maximizer, resulting in the belief that managers may act in their own interests and may not always act in the best interests of shareholders (Jensen and Meckling, 1976). It is highly likely that agency conflicts are present in HIO firms, as managers in HIO firms have superior knowledge about their firm's investment opportunities and investment options depend on discretionary expenditures made by managers (Myers, 1977; Lai, 2009). As such, managerial discretion relating to high investment opportunities may lead to management pursuing their own interests at the expense of shareholders (Opler et al., 1999; Belghitar and Khan, 2013). The high agency costs and increasing uncertainty in HIO firms heighten firm risk and require frequent monitoring (Lai, 2009).

\subsection{Related research on investment opportunities}

Prior studies on investment opportunities mainly focus on either firm characteristics related to growth opportunities, the impact of high investment opportunities on managerial behaviors and management's decision making (Smith \& Watts, 1992; Gaver \& Gaver, 1993; Skinner, 1993; Baber et al., 1996; Cahan et al., 2008; Kumar \& Krishna, 2008; Lai, 2009; Chen, Elder, \& Hung, 2010; Boudry, Kallberg, \& Liu, 2013; McGuire, Omer, \& Wilde, 2014) or governance mechanisms in firms with high investment opportunities (Lai, 2009; Chen et al., 2010; Belghitar \& Khan 2013). Examining the industry-level data from 1965-1985, Smith \& Watts (1992) find U.S. firms with lower level of leverage and lower dividend yields have greater investment options for positive net present value projects. Firms with high investment opportunities are also likely to have higher executive compensation, and less likely to use stock options and bonus plans. Examining 1249 U.S. firms during the 1992-1993 period, Baber et al. (1996) conclude investment opportunities and the sensitivity of CEO compensation to performance measures are related. They also suggest firms with high investment opportunities have greater sensitivity to market-based performance indicators. With the sample of 139 Real Estate Investment Trust (REITs) from 1996 to 2010, Boudry et al.'s (2013) find the 
level of share repurchases is lower in firms with HIO and investment opportunities are negatively associated with share repurchase announcement returns.

High investment opportunities have been found to have adverse effects on earnings quality. The impact of high investment opportunities on earnings quality is documented to be mitigated by both internal and external corporate governance. Using unregulated industrial firms listed on the New York Stock Exchange, the American Stock Exchange, and the National Association of Securities Dealers Automated Quotation, Lai (2009) investigated whether investment opportunities are associated with the probability of earnings management. He finds earnings management (as proxied by discretionary accruals) is more likely to occur in firms with high investment opportunities. Lai (2009) also documents a weaker relationship between high investment opportunities and earnings management if firms are audited by a Big 5 accounting firm. Similarly, Chen et al. (2010) obtained a sample of 3622 firm-year observations from Taiwan Economic Journal for the 2002-2005 period. They report a higher likelihood of earnings management in firms with high investment opportunities. Earnings management level is lower if the HIO firms have greater cash flow rights of controlling shareholders. They also indicate firms with high investment opportunities and a high variation between cash flow rights and control rights of controlling shareholders are more likely to manage earnings. Using the sample of U.K. small to medium-sized firms during the 2005-2008 period, Belghitar \& Khan (2013) conclude the effectiveness of internal and external corporate governance mechanisms depends on the level of investment opportunities. The study reveals internal corporate governance mechanisms are more effective for high investment opportunity firms and external governance mechanisms are more effective for low investment opportunity firms.

\subsection{Determinants of audit report lags}

Prior studies examine a variety of factors influencing audit report lags. Table 1 presents a summary of determinants of audit report lags found in prior research.

Table 1. Determinants of audit report lag in prior research

\begin{tabular}{|c|c|c|}
\hline \# & Author(s) and Year & Determinants of Audit Report Lag \\
\hline 1 & Ashton et al. (1989) & $\begin{array}{l}\text { Auditor size, industry classification, existence of extraordinary } \\
\text { items, and sign of net income }\end{array}$ \\
\hline 2 & Newton and Ashton (1989) & Audit technology \\
\hline 3 & Bamber et al. (1993) & $\begin{array}{l}\text { The amount of audit work required, incentive to provide more } \\
\text { timely audit reports, and the extent of using a structured audit } \\
\text { approach }\end{array}$ \\
\hline 4 & Kinney and McDaniel (1993) & The correction of previously reported interim earnings \\
\hline 5 & Schwartz and Soo (1996) & The timing of auditor changes \\
\hline 6 & Jaggi and Tsui (1999) & $\begin{array}{l}\text { Client firms' financial conditions, and structured/unstructured } \\
\text { audit approach }\end{array}$ \\
\hline 7 & Knechel and Payne (2001) & $\begin{array}{l}\text { Incremental audit effort, the presence of contentious tax issues, } \\
\text { and audit staff experience }\end{array}$ \\
\hline 8 & Leventis et al. (2005) & $\begin{array}{l}\text { Auditor type, audit fees, number of remarks in the audit report, } \\
\text { the presence of extraordinary items, and expression of } \\
\text { uncertainty in the audit report. }\end{array}$ \\
\hline 9 & Behn et al. (2006) & Lack of sufficient personnel resources \\
\hline 10 & Ettredge et al. (2006) & Material weakness in internal control \\
\hline 11 & Bonson-Ponte et al. (2008) & Regulatory pressure, and company size \\
\hline 12 & Lee et al. (2009) & Auditor tenure, and nonaudit services \\
\hline 13 & Tanyi et al. (2010) & Voluntary and involuntary auditor changes \\
\hline 14 & Habib and Bhuiyan (2011) & Audit firm industry specialization \\
\hline
\end{tabular}

Generally, prior studies show audit report lags are determined by some firm characteristics such as the existence of extraordinary items, net income (e.g., Ashton et al., 1987; Leventis et al., 2005), the timing and type of auditor changes (Schwartz \& Soo, 1996; Tanyi et al., 2010), material weakness in internal control (Ettredge et al., 2006). 
Using a sample of 465 firms listed on the Toronto Stock Exchange during the period 1977-1982, Ashton et al. (1989) investigate factors that determine the timing of audit reports. They find industry classification, the existence of extraordinary items, and net income are determinants of audit report lags. Using a sample of 198 ex-Andersen clients and 120 other Big 5 clients with a December 31, 2002 fiscal year-end, Tanyi et al. (2010) find that audit report lags in U.S. firms with involuntary auditor changes are significantly higher than in firms with voluntary auditor changes. They also indicate firms with voluntary auditor changes have marginally higher auditor changes. In another study, Ettredge et al. (2006) examine 3098 firms filing Sarbanes-Oxley Act (SOX) Section 404 reports from January 2005 to June 2005. They find material weakness in internal control results in longer audit lags. The length of audit delays depends on the types of material weakness; that is, audit delays are longer for general material weakness compared to specific material weakness.

In addition, prior research finds audit report lags are associated with auditor-related characteristics including auditor size/auditor type (Ashton et al., 1989; Leventis et al., 2005), audit technology (Newton \& Ashton, 1989; Bamber et al., 1993; Jaggi \& Tsui, 1999), the amount of audit work required and audit effort (Bamber et al., 1993; Knechel \& Payne, 2001), the incentive to provide timely audit reports (Bamber et al., 1993), audit fees, number of remarks in the audit reports, audit staff experience (Behn et al., 2006), auditor tenure, nonaudit services (Lee et al., 2009), and audit firm industry specialization (Habib \& Bhuiyan, 2011). Examining 171 firms listed on Athens Stock Exchange as of December 31, 2000, Leventis et al. (2005) report significant relationships exist between audit report delay and auditor type, audit fees, the number of remarks in the audit report, and an expression of uncertainty in the audit report. Specifically, Leventis et al. (2005) conclude audit report lag is longer in firms audited by local audit firms (as compared to international audit firms), charged lower audit fees, and with uncertainty expression in the audit report. With 18473 firm-year observations from 2000 to 2005, Lee et al. (2009) find firms audited by long tenured auditors have shorter audit report delays. Moreover, they find the provision of nonaudit services leads to the increase in learning and shorter audit report lags (Lee et al., 2009). The study of 105 firms listed on New Zealand stock exchange during the 2004-2008 period by Habib \& Bhuiyan (2011) reveals audit report delay is shorter in firms being audited by an industry specialist.

In addition to firm-related and auditor-related factors, extant accounting literature documents other associations with audit report lags. For instance, Bonson-Ponte et al. (2008) investigated 136 firms listed on the Spanish continuous market at the end of the year 2004 and conclude regulatory pressure is associated with audit report lag. The study of 85 U.S. firms announcing the corrections of previously reported interim earnings in their 1976-1988 annual reports shows the corrections of misstatements in previously reported interim earnings may also increase audit delay (Kinney \& McDaniel, 1993). Overall, the accounting literature suggests various factors influence audit report lags. Our paper extends this line of research by examining whether investment opportunities are associated with audit report delay.

\subsection{Hypothesis development}

Prior research shows the level of investment opportunities may influence management's decision making (e.g., executive compensation, share repurchases, and so on) and earnings quality; however, whether high levels of investment opportunities result in longer audit delays remains unanswered. In a sample of 650 Hong Kong firms, for the period of 1994-1996, Tsui et al. (2001) find it is difficult to monitor high investment opportunity firms because of future discretionary investment expenditures and the challenge in observing managements' activities. Firms with high investment opportunities were found to have weak internal control systems and less reliable accounting system, leading to higher audit risk and greater audit effort (Tsui et al., 2001; Lai, 2009). Likewise, examining a sample of U.S. firms for the period 1984 to 2004, Cahan et al. (2008) indicate audit risk increases in HIO firms. The reason inherent risk is high for firms with HIO is because of a higher likelihood of managerial opportunism relating to HIO set. The increase in audit risk also results from higher control risk due to the intricacy of monitoring growth options. Moreover, the increase in complexity and uncertainty associated with investment opportunities leads to an increase in detection risk. Because of the heightened risk, auditors of HIO firms need to put more effort into, and expand the scope of, the audit work.

Using a sample of 972 U.S. firm-year observations, Bamber et al. (1993) construct an audit report lag model that includes all determinants of audit report lags. In Bamber et al.'s (1993) model, audit report lags are determined by three main factors: (1) the required amount of audit work, (2) the incentives to provide timely audit reports, and (3) the extent of the auditor's use of a structured audit approach. This model suggests auditors would need to increase the scope of their audit work to accommodate the increased audit risks in HIO firms. Accordingly, we expect firms 
with high investment opportunities to have longer audit report delays. This leads to our hypothesis (stated in alternative form).

H1: There is a positive relationship between the level of investment opportunities and audit report lag.

\section{Research method}

\subsection{Regression model}

We follow prior research on audit report lags (e.g., Ettredge et al., 2006; Lee et al., 2009; Habib \& Bhuiyan, 2011) to construct a regression model to examine the association between investment opportunities and audit report lag. Our model is as follows:

$$
\begin{aligned}
A R L & =\alpha_{0}+\alpha_{1} * \text { InvestOpp }+\alpha_{2} * R O A+\alpha_{3} * S E G N U M+\alpha_{4} * \text { LOSS }+\alpha_{5} * G C+\alpha_{6} * Y E N D \\
& +\alpha_{7} * B I G 4+\alpha_{8} * \text { SIZE }+\alpha_{9} * \text { MWIC }+\alpha_{10} * A U D C H G+\alpha_{11} * \text { IndustryDummies } \\
& +\alpha_{12} * \text { YearDummies }+\varepsilon
\end{aligned}
$$

\begin{tabular}{|c|c|c|}
\hline$A R L$ & $=$ & number of calendar days from fiscal year-end to the date of the auditor's report; \\
\hline InvestOpp & $=$ & investment opportunity factor; \\
\hline ROA & & net earnings divided by total assets; \\
\hline SEGNUM & $=$ & reportable segments of a client; \\
\hline LOSS & $=$ & 1 if a firm reports negative earnings, 0 otherwise; \\
\hline$G C$ & $=$ & 1 if the firm received a going concern opinion, 0 otherwise; \\
\hline$Y E N D$ & $=$ & 1 if a firm's fiscal year ends in December, and 0 otherwise; \\
\hline$B I G 4$ & $=$ & 1 if an auditor is one of the Big 4 auditing firms, and 0 otherwise; \\
\hline SIZE & $=$ & natural log of total assets; \\
\hline$M W I C$ & $=$ & 1 if a firm has material weakness in internal control, and 0 otherwise; \\
\hline$A U D C H G$ & $=$ & 1 if the client firm changed auditor during the current year, 0 otherwise; \\
\hline IndustryDummies & $=$ & industry dummies; \\
\hline YearDummies & $=$ & year dummies. \\
\hline
\end{tabular}

Where,

\subsubsection{Dependent variable and test variables}

The dependent variable, $A R L$, provides information on the length of the audit report lag. Our variable of interest in Model (1) is investment opportunity factor, InvestOpp. Following Lai (2009), we use factor analysis and three proxies for investment opportunities to develop an investment opportunity factor. The three proxies for investment opportunities include market-to-book asset (FIRMASS); market-to-book equity (MKTBEQ); and gross property, plant and equipment ratio (PPEGT). If firms with high levels of investment opportunities have longer audit report lag, the coefficient on InvestOpp is expected to be positive and significant.

\subsubsection{Control variables}

We include the following control variables that have been used in prior research (e.g., Ettredge et al., 2006; Lee et al., 2009; Habib \& Bhuiyan, 2011): return on assets (ROA), number of a client's reportable segment (SEGNUM), negative earnings (LOSS), going concern audit opinion (GC), fiscal year ending in December (YEND), Big 4 accounting firms (BIG4), firm size (SIZE), material weakness in internal control (MWIC), and auditor change $(A U D C H G)$. Based on the results of prior studies, we expect the coefficients on ROA, SEGNUM, LOSS, YEND, $M W I C$ and $A U D C H G$ to be positive and the coefficients on BIG 4 and SIZE to be negative.

\subsection{Data and sample selection}

The study is based on a sample of U.S. firms for the 2010-2012 period. The initial sample consists of firms having available data from Compustat and Audit Analytics databases to calculate audit report lag. Financial information is collected from Compustat database. We obtain audit fee data, restatement, material weakness in internal control, and auditor changes from Audit Analytics database. The eliminations of some financial data, data in Audit Analytic database, and data to calculate investment opportunities due to insufficient information in respective databases leave a final sample of 8520 firm-year observations. The sample selection process is reported in Table 2. 
Table 2. Sample selection

\begin{tabular}{lr}
\hline Sample with data being available to calculate ARL & 12416 \\
Less: & \\
& Missing investment opportunity data \\
Missing other financial data & 3084 \\
Missing data in Audit Analytic database & 576 \\
Final sample & 8520
\end{tabular}

\section{Results}

\subsection{Descriptive statistics}

Table 3 presents the descriptive statistics of our dependent and independent variables. All variables (except for indicator variables) are winsorized at the $1^{\text {st }}$ and $99^{\text {th }}$ percentiles to mitigate the effect of outliers. On average, our sample firms have audit report delays ( $A R L)$ of 66 days. The average value of investment opportunity (InvestOpp) is 1.083. The return on asset ratio $(R O A)$ has a mean (median) of $0.003(0.042)$. On average, each firm has two business segments. About 26 percent of the sample firms reported negative earnings during the fiscal year while approximately two percent of the sample firms received going concern opinions. Seventy-four percent of the sample firms have the fiscal year ending in December; meanwhile, on average, 85 percent of firms are audited by one of the Big 4 accounting firms. The average value of total assets of our sample firms is $\$ 7196$ million. Among the sample firms, 3.3 percent of the firms reported a material weakness in internal control. Finally, 3.4 percent of the sample firms changed their auditors during the study period.

Table 3. Descriptive statistics $(\mathrm{N}=8520)$

\begin{tabular}{|c|c|c|c|c|c|}
\hline$\underline{\text { Variable }}$ & Mean & $\frac{\text { Standard }}{\text { Deviation }}$ & $\underline{25 \text { th }}$ & $\underline{\text { Median }}$ & $\frac{75 \text { th }}{\text { Percentile }}$ \\
\hline$A R L$ & 66.046 & 21.035 & 55.000 & 60.000 & 73.000 \\
\hline InvestOpp & 1.083 & 0.637 & 0.632 & 0.925 & 1.372 \\
\hline$R O A$ & 0.003 & 0.193 & -0.003 & 0.042 & 0.083 \\
\hline SEGNUM & 2.246 & 1.816 & 1.000 & 1.000 & 3.000 \\
\hline LOSS & 0.258 & 0.437 & 0.000 & 0.000 & 1.000 \\
\hline$G C$ & 0.018 & 0.132 & 0.000 & 0.000 & 0.000 \\
\hline YEND & 0.736 & 0.441 & 0.000 & 1.000 & 1.000 \\
\hline$B I G 4$ & 0.849 & 0.358 & 1.000 & 1.000 & 1.000 \\
\hline SIZE & 20.843 & 1.905 & 19.497 & 20.720 & 22.068 \\
\hline AT (\$millions) & 7196.010 & 24118.780 & 293.307 & 996.683 & 3835.750 \\
\hline$M W I C$ & 0.033 & 0.179 & 0.000 & 0.000 & 0.000 \\
\hline$A U D C H G$ & 0.034 & 0.181 & 0.000 & 0.000 & 0.000 \\
\hline
\end{tabular}

Notes: $A R L=$ number of calendar days from fiscal year-end to the date of the auditor's report; InvestOpp $=$ investment opportunity factor; $R O A=$ net earnings divided by total assets; $S E G N U M=$ number of reportable segments of a client; $L O S S=1$ if a firm reports negative earnings, 0 otherwise; $G C=1$ if the firm received a going concern opinion, 0 otherwise; $Y E N D=1$ if a firm's fiscal year ends in December, 0 otherwise; $B I G 4=1$ if an auditor is one of the Big 4 auditing firms, 0 otherwise; SIZE = natural log of total assets; $A T=$ Total assets; $M W I C=$ 1 if a firm has material weakness in internal control, 0 otherwise; and $A U D C H G=1$ if the client firm changed auditor during the current year, 0 otherwise. 
Table 4. Audit report lag by industry

\begin{tabular}{|c|c|c|c|c|}
\hline \multirow[b]{2}{*}{ \# } & \multirow[b]{2}{*}{ Industry (SICs) } & \multicolumn{2}{|c|}{ Sample Firms } & \multirow[b]{2}{*}{$A R L$} \\
\hline & & Number & Percent & \\
\hline 1 & $\begin{array}{l}\text { Consumer NonDurables (0100-0999, 2000-2399, 2700-2749, } \\
2770-2799,3100-3199,3940-3989)\end{array}$ & 418 & $4.91 \%$ & 64.91 \\
\hline 2 & $\begin{array}{l}\text { Consumer Durables }(2500-2519,2590-2599,3630-3659 \text {, } \\
\text { 3710-3711, 3714-3714, 3716-3716, 3750-3751, 3792-3792, } \\
\text { 3900-3939, 3990-3999) }\end{array}$ & 251 & $2.95 \%$ & 64.67 \\
\hline 3 & $\begin{array}{l}\text { Manufacturing }(2520-2589,2600-2699,2750-2769,3000-3099, \\
3200-3569,3580-3629,3700-3709,3712-3713,3715-3715 \text {, } \\
3717-3749,3752-3791,3793-3799,3830-3839,3860-3899)\end{array}$ & 942 & $11.06 \%$ & 63.52 \\
\hline 4 & $\begin{array}{l}\text { Oil, Gas, and Coal Extraction and Products (1200-1399, } \\
\text { 2900-2999) }\end{array}$ & 606 & $7.11 \%$ & 65.43 \\
\hline 5 & Chemicals and Allied Products (2800-2829, 2840-2899) & 251 & $2.95 \%$ & 59.51 \\
\hline 6 & $\begin{array}{l}\text { Business Equipment }(3570-3579,3660-3692,3694-3699 \text {, } \\
3810-3829,7370-7379)\end{array}$ & 1743 & $20.46 \%$ & 66.79 \\
\hline 7 & Telephone and Television Transmission (4800-4899) & 370 & $4.34 \%$ & 74.05 \\
\hline 8 & Utilities (4900-4949) & 349 & $4.10 \%$ & 63.43 \\
\hline 9 & $\begin{array}{l}\text { Wholesale, Retail, and Some Services (Laundries, Repair Shops) } \\
(5000-5999,7200-7299,7600-7699)\end{array}$ & 859 & $10.08 \%$ & 62.28 \\
\hline 10 & $\begin{array}{l}\text { HealthCare, Medical Equipment, and Drugs (2830-2839, } \\
\text { 3693-3693, 3840-3859, 8000-8099) }\end{array}$ & 1064 & $12.49 \%$ & 65.75 \\
\hline 11 & Financial Institutions (6000-6999) & 300 & $3.52 \%$ & 65.51 \\
\hline \multirow[t]{2}{*}{12} & Others & $\underline{1367}$ & $\underline{16.04 \%}$ & 70.04 \\
\hline & Total & 8520 & $100 \%$ & \\
\hline
\end{tabular}

Table 4 reports the sample industry breakdown and the average audit report lag for each industry during the study period. As indicated in Table 4, our sample firms spread across a wide range of industries. A large number of sample firms are in the Business Equipment industry group (20.46 percent). Health Care, Medical Equipment, and Drugs industry group accounts for 12.49 percent of the total sample while manufacturing industry group makes up 11.06 percent of the sample firms. Consumer Durables and Chemicals and Allied Products are the two industry groups that have the lowest number of sample firms. In terms of audit report lag, Table 4 indicates that Telephone and Television Transmission industry has the longest audit delay during our study period (74.05 days). Meanwhile, Wholesale, Retail, and some Services (laundries, repair shops) has the lowest level of audit report lag (62.28 days). 
Table 5. Correlation matrix $(\mathrm{N}=8520)$

\begin{tabular}{|c|c|c|c|c|c|c|c|c|c|c|c|}
\hline & $A R L$ & InvestOpp & $R O A$ & SEGNUM & LOSS & $G C$ & YEND & $B I G 4$ & SIZE & $M W I C$ & $A U D C H G$ \\
\hline$A R L$ & 1.00 & $0.07 * * *$ & $-0.13 * * *$ & -0.01 & $0.16^{* * *}$ & $0.11 * * *$ & $0.07 * * *$ & $-0.11 * * *$ & $-0.18 * * *$ & $0.20 * * *$ & $0.09 * * *$ \\
\hline Invest $O p p$ & $0.03 * * *$ & & $-0.15^{* * *}$ & $-0.03 * *$ & $0.16^{* * *}$ & $0.13 * * *$ & $0.07 * * *$ & $-0.04 * * *$ & 0.003 & 0.01 & $0.03 * *$ \\
\hline$R O A$ & $-0.23 * * *$ & $-0.11 * * *$ & & $0.13 * * *$ & $-0.65 * * *$ & $-0.33 * * *$ & $-0.067 * * *$ & $0.14 * * *$ & $0.37 * * *$ & $0.08 * * *$ & $-0.05 * * *$ \\
\hline SEGNUM & $-0.06^{* * *}$ & $-0.03 * *$ & $0.07 * * *$ & & $-0.16^{* * *}$ & $-0.05 * * *$ & -0.02 & $0.08 * * *$ & $0.30 * * *$ & -0.01 & $-0.02 *$ \\
\hline$L O S S$ & $0.25 * * *$ & $0.11 * * *$ & $-0.76 * * *$ & $-0.15 * * *$ & & $0.20 * * *$ & $0.06 * * *$ & $-0.11 * * *$ & $-0.34 * * *$ & $0.10 * * *$ & $0.05 * * *$ \\
\hline$G C$ & $0.13 * * *$ & $0.09 * * *$ & $-0.18 * * *$ & $-0.04 * * *$ & $0.20 * * *$ & & 0.01 & $-0.11 * * *$ & $-0.17 * * *$ & $0.08 * * *$ & $0.04 * * *$ \\
\hline YEND & $0.07 * * *$ & $0.06^{* * *}$ & $-0.09 * * *$ & -0.02 & $0.06^{* * *}$ & 0.01 & & $0.04 * * *$ & $0.04 * * *$ & 0.002 & 0.01 \\
\hline$B I G 4$ & $-0.21 * * *$ & $-0.02 *$ & $0.07 * * *$ & $0.06 * * *$ & $-0.11 * * *$ & $-0.11 * * *$ & $0.04 * * *$ & & $0.38 * * *$ & $-0.10 * * *$ & $-0.10 * * *$ \\
\hline SIZE & $-0.41 * * *$ & $0.05 * * *$ & $0.22 * * *$ & $0.23 * * *$ & $-0.34 * * *$ & $-0.14 * * *$ & $0.04 * * *$ & $0.38 * * *$ & & $-0.10 * * *$ & $-0.07 * * *$ \\
\hline$M W I C$ & $0.19 * * *$ & -0.01 & $-0.08 * * *$ & -0.005 & $0.10^{* * *}$ & $0.08 * * *$ & 0.00 & $-0.10 * * *$ & $-0.10^{* * *}$ & & $0.11 * * *$ \\
\hline$A U D C H G$ & $0.10 * * *$ & $0.02 *$ & $-0.04 * * *$ & -0.02 & $0.05 * * *$ & $0.04 * * *$ & 0.01 & $-0.10 * * *$ & $-0.08 * * *$ & $0.11^{* * *}$ & 1.00 \\
\hline
\end{tabular}

Notes: $(* * *),(* *)$ and $(*)$ : Significant at $p=0.01,0.05$ and 0.10 levels. Pearson (Spearman) correlations are above (below) the diagonal. Variables are defined in Table 3.

Table 5 presents a correlation matrix between audit report lag and the test and control variables used in the primary model. We find numerous significant correlations between the study variables. Particularly, audit report lag $(A R L)$ is has a positive and significant relationship with investment opportunities (InvestOpp). The result is consistent with our hypothesis. We also find that $A R L$ is positively associated with negative earnings ( $L O S S$ ), going concern opinion $(G C)$, fiscal year ending in December (YEND), material weakness in internal control (MWIC), and auditor changes $(A U D C H G)$. As expected, Table 5 shows $A R L$ is negatively related to BIG4 and SIZE, respectively. The examination of variance inflation factor (VIF) scores reveals that all of the scores are less than 2.1, indicating that multicollinearity is not a problem.

\subsection{Multiple regression results}

Table 6. Regression results: Investment opportunities and audit report lags

\begin{tabular}{lllll}
\hline Variable & Coefficient & t-stat & p-value & VIF \\
Intercept & 73.924 & 56.360 & $\mathbf{0 . 0 0 0}$ & 0.000 \\
InvestOpp & 1.381 & 3.750 & $\mathbf{0 . 0 0 0}$ & 1.195 \\
ROA & 0.414 & 0.260 & 0.398 & 2.064 \\
SEGNUM & 0.661 & 5.190 & $\mathbf{0 . 0 0 0}$ & 1.164 \\
LOSS & 4.142 & 6.260 & $\mathbf{0 . 0 0 0}$ & 1.821 \\
GC & 8.016 & 4.610 & $\mathbf{0 . 0 0 0}$ & 1.149 \\
YEND & 3.035 & 5.920 & $\mathbf{0 . 0 0 0}$ & 1.110 \\
BIG4 & -1.257 & -1.910 & $\mathbf{0 . 0 2 8}$ & 1.210 \\
SIZE & -1.707 & -11.710 & $\mathbf{0 . 0 0 0}$ & 1.619 \\
MWIC & 20.037 & 16.420 & $\mathbf{0 . 0 0 0}$ & 1.035 \\
AUDCHG & 6.378 & 5.310 & $\mathbf{0 . 0 0 0}$ & 1.025 \\
IndustryDummies & & Controlled & & \\
YearDummies & & Controlled & & \\
Adj R2 & & $11.58 \%$ & & \\
F-stat & & 48.36 & & \\
p-value & $<0.001$ & & \\
N & & 8520 & & \\
\hline
\end{tabular}


Notes: The p-values are one-tailed. Variables are defined as follows: Dependent variable is $A R L$ which is the number of calendar days from fiscal year-end to the date of the auditor's report; InvestOpp = investment opportunity factor; $R O A=$ net earnings divided by total assets; $S E G N U M=$ number of reportable segments of a client; $L O S S=1$ if a firm reports negative earnings, 0 otherwise; $G C=1$ if the firm received a going concern opinion, 0 otherwise; $Y E N D$ $=1$ if a firm's fiscal year ends in December, 0 otherwise; $B I G 4=1$ if the auditor is one of the Big 4 auditing firms, 0 otherwise; $S I Z E=$ natural $\log$ of total assets; $M W I C=1$ if a firm has material weakness in internal control, 0 otherwise; $A U D C H G=1$ if the client firm changed auditor during the current year, 0 otherwise; IndustryDummies $=$ industry dummies; and YearDummies $=$ year dummies.

Table 6 provides the regression results of estimating equation (1), which tests whether there is an association between investment opportunities and audit report lag. The dependent variable is $A R L$ which is the number of calendar days from fiscal year-end to the date of the auditor's report. The overall model is significant (F-statistics $=48.36, p$-value $<0.001$ ) with the adjusted $\mathrm{R}^{2}$ of $11.58 \%$.

The coefficient on the variable of interest, InvestOpp, is positive and significant $(1.381, p$-value $=0.000)$. This indicates firms with high levels of investment opportunities are more likely to have longer audit report lag. The result supports our hypothesis. The result is also consistent with the reasoning that the long audit delays in high investment opportunity firms result from the increase in audit risk that requires auditors to exert more effort and expand the scope of audit work.

The coefficients on the control variables are generally consistent with our predictions. We find audit report lag is negatively associated with BIG4 $(-1.257 ; p$-value $=0.028)$ and SIZE $(-1.707, p$-value $=0.000)$, suggesting that smaller firms and firms being audited by non-Big 4 accounting firms tend to have longer audit report lag. The result is consistent with prior studies' findings (e.g., Ettredge et al., 2006; Habib and Bhuiyan, 2011). We also find ARL is positively related to SEGNUM, LOSS, GC, YEND, MWIC, and AUDCHG. Specifically, firms tend to have longer audit delays when they have more business segments, report negative earnings, receive going concern audit opinions and report material weaknesses in internal controls. Client firms with a December fiscal year-end or who changed their auditors in the current year are also found to have longer audit report lag.

\subsection{Additional analyses}

\subsubsection{Abnormal audit report lag}

Prior research (e.g., Bamber et al., 1993; Habib and Bhuiyan, 2011) distinguishes total audit report lag from abnormal audit report lag. We therefore conduct a sensitivity test replacing audit report lag in Model (1) with abnormal audit report lag $(A b A R L)$. Abnormal audit report lag is measured as the difference between the current year's audit report lag and the median audit report lag over the study period. We also replace InvestOpp variable in Model (1) with AbInvestOpp, which is the difference between the current year's investment opportunities and the median investment opportunities. The model is constructed as follows:

$$
\begin{aligned}
\text { AbARL } & =\alpha_{0}+\alpha_{1} * \text { AbInvestOpp }+\alpha_{2} * R O A+\alpha_{3} * \text { SEGNUM }+\alpha_{4} * \text { LOSS }+\alpha_{5} * G C+\alpha_{6} * \text { YEND } \\
& +\alpha_{7} * \text { BIG } 4+\alpha_{8} * \text { SIZE }+\alpha_{9} * \text { MWIC }+\alpha_{10} * A U D C H G+\alpha_{11} * \text { IndustryDummies } \\
& +\alpha_{12} * \text { YearDummies }+\varepsilon
\end{aligned}
$$

The variables in Model (2) are defined as stated earlier. The results are shown in Table 7. The variable of interest, AbInvestOpp, is not significantly related to $A b A R L$; however, the coefficient on AbInvestOpp is positive. The positive coefficient on AbInvestOpp is consistent with our prediction that HIO firmss are more likely to have longer audit report lag. Consistent with the results reported in Table 6, we find that abnormal audit report lag is positively associated with $G C, M W I C$ and $A U D C H G$. This indicates that firms receiving going concern opinion, reporting material weakness in internal control, and changing auditors are more likely to have unexpected audit report delay. 
Table 7. Regression results: High investment opportunities and abnormal audit report lags

\begin{tabular}{lllll}
\hline Variable & Coefficient & $\mathrm{t}$-stat & $\mathrm{p}$-value & $\mathrm{VIF}$ \\
Intercept & -1.291 & -2.360 & $\mathbf{0 . 0 0 9}$ & 0.000 \\
AbInvestOpp & 0.425 & 1.070 & 0.143 & 1.012 \\
ROA & 0.058 & 0.080 & 0.467 & 2.061 \\
SEGNUM & 0.048 & 0.860 & 0.194 & 1.162 \\
LOSS & 0.190 & 0.660 & 0.256 & 1.806 \\
GC & 1.548 & 2.030 & $\mathbf{0 . 0 2 1}$ & 1.142 \\
YEND & 0.161 & 0.720 & 0.237 & 1.110 \\
BIG4 & 0.285 & 0.980 & 0.163 & 1.210 \\
SIZE & 0.066 & 1.030 & 0.151 & 1.619 \\
MWIC & 7.674 & 14.300 & $\mathbf{0 . 0 0 0}$ & 1.035 \\
AUDCHG & 0.774 & 1.470 & $\mathbf{0 . 0 7 1}$ & 1.025 \\
IndustryDummies & & Controlled & & \\
YearDummies & & Controlled & & \\
Adj R2 & & $3.70 \%$ & & \\
F-stat & & 14.18 & & \\
p-value & & $<0.001$ & & \\
N & & 8,520 & \\
\hline
\end{tabular}

Notes: The p-values are one-tailed. Variables are defined as follows: Dependent variable is $A b A R L$ which is the difference between the current year' ARL and the median ARL over the study period; AbInvestOpp $=$ the difference between the current year's investment opportunity and the median investment opportunities; $R O A=$ net earnings divided by total assets; $S E G N U M=$ number of reportable segments of a client; $L O S S=1$ if a firm reports negative earnings, 0 otherwise; $G C=1$ if the firm received a going concern opinion, 0 otherwise; $Y E N D=1$ if a firm's fiscal year ends in December, 0 otherwise; BIG4 = 1 if the auditor is one of the Big 4 auditing firms, 0 otherwise; SIZE $=$ natural $\log$ of total assets; $M W I C=1$ if a firm has material weakness in internal control, 0 otherwise; $A U D C H G=1$ if the client firm changed auditor during the current year, 0 otherwise; IndustryDummies = industry dummies; and YearDummies $=$ year dummies.

4.3.2 Abnormal audit report lag, investment opportunities, and future financial restatements

Blankley et al. (2014) examine the association between audit report lags and future financial restatements. They find abnormal audit report lags are longer for firms that subsequently restate their financial statements in future periods. Hence, we perform an additional analysis to (1) reexamine the relationship between abnormal audit report lag and future restatements, and (2) investigate whether firms with high level of investment opportunities and high abnormal audit report lags are more likely to restate their financial restatements in future periods. We use the following model:

$$
\begin{aligned}
\text { RESTATE_F } & =\alpha_{0}+\alpha_{1} * \text { AbARL }+\alpha_{2} * \text { InvestOPp_High }+\alpha_{3} * \text { AbARL_HighInvest }+\alpha_{4} * \text { SIZE } \\
& +\alpha_{5}{ }^{*} \text { LEVERAGE }+\alpha_{6} * \text { MTB }+\alpha_{7} * \text { FIN }+\alpha_{8} * \text { EPR }+\alpha_{9} * \text { FREEC } \\
& +\alpha_{11} * \text { IndustryDummies }+\alpha_{12} * \text { YearDummies }+\varepsilon
\end{aligned}
$$

Where, RESTATE_F which is the probability of financial restatements in the year following the study year; $A b A R L=$ the difference between the current year' ARL and the median ARL over the study period; InvestOpp_High $=1$ if the current year's investment opportunity level is higher than the median investment opportunities, 0 otherwise; AbARL_HighInvest $=$ interaction term between $A b A R L$ and InvestOpp_High; SIZE $=$ natural log of total assets; LEVERAGE = Total debt divided by total assets; $M T B=$ Market-to-book ratio; FIN = financing raised, defined as the sum of additional cash raised from issuance of long-term debt, common stock and preferred stock deflated by total assets; $E P R=$ earnings-to-price ratio, defined as income from continuing operations scaled by market capitalization at the end of the year; FREEC = demand for external financing, measured as the sum of cash from operations less capital expenditures scaled by lagged total assets. 
Table 8. Regression results: Abnormal audit report lags and future financial restatements

\begin{tabular}{lcccc}
\hline Variable & Coefficient & t-stat & p-value & VIF \\
Intercept & 0.050 & 4.090 & $\mathbf{0 . 0 0 0}$ & 0.000 \\
AbARL & 0.001 & 1.520 & $\mathbf{0 . 0 6 5}$ & 2.021 \\
Invest_Pp_High & -0.004 & -0.820 & 0.206 & 1.203 \\
AbAR__HighInvest & -0.001 & -1.070 & 0.142 & 2.014 \\
SIZE & -0.003 & -1.830 & $\mathbf{0 . 0 3 4}$ & 1.346 \\
LEVERAGE & 0.056 & 4.410 & $\mathbf{0 . 0 0 0}$ & 1.322 \\
MTB & 0.000 & 0.230 & 0.408 & 1.012 \\
FIN & 0.000 & 0.050 & 0.481 & 1.213 \\
EPR & 0.000 & -1.200 & 0.115 & 1.005 \\
FREEC & -0.002 & -0.210 & 0.418 & 1.345 \\
IndustryDummies & & Controlled & & \\
YearDummies & & Controlled & & \\
Adj R2 & & $1.31 \%$ & & \\
F-stat & & 5.94 & & \\
p-value & & $<0.001$ & & \\
N & & 8,162 & & \\
\hline
\end{tabular}

Notes: The p-values are one-tailed. Variables are defined as follows: Dependent variable is RESTATE_ $F$ which is the probability of financial restatements in the year following the study year; $A b A R L=$ the difference between the current year' ARL and the median ARL over the study period; InvestOpp_High $=1$ if the current year's investment opportunity level is higher than the median investment opportunities, 0 otherwise; AbARL_HighInvest $=$ the interaction term between AbARL and InvestOpp_High; SIZE = natural log of total assets; LEVERAGE = Total debt divided by total assets; $M T B=$ Market-to-book ratio; FIN = financing raised, defined as the sum of additional cash raised from issuance of long-term debt, common stock and preferred stock deflated by total assets; EPR = earnings-to-price ratio, defined as income from continuing operations scaled by market capitalization at the end of the year; FREEC = demand for external financing, measured as the sum of cash from operations less capital expenditures scaled by lagged total assets; IndustryDummies $=$ industry dummies; and YearDummies $=$ year dummies.

The results are presented in Table 8. Consistent with Blankley et al.'s (2014) results, we find a positive relation between future financial restatements (RESTATE_F) and abnormal audit report lags $(A b A R L)(0.001 ; p$-value $=$ 0.065). This indicates that firms with longer audit report lags are more likely to incur future restatements. This finding supports the view that unusually long audit delays provide a signal of a problematic audit.

\subsection{Sensitivity tests}

\subsubsection{Big 4 clients}

We test the robustness of our results by controlling for auditor type. Leventis et al. (2005) show that auditor type is one of the determinants of audit report lags. Meanwhile, Lai (2009) concludes firms with high investment opportunities tend to hire Big 5 accounting firms. Hence, we conduct a sensitivity test on a sample including only Big 4 clients. The untabulated results are relatively consistent with those reported in Table 6 .

4.4.2 Client firms with material weakness in internal control

Ettredge et al.'s (2006) study reveals material weakness in internal control leads to longer audit delays. While we control for this effect in our primary model, as a sensitivity test, we rerun Model (1) on the sample of firms having material weakness in internal control. The results are not tabulated. We find that our primary result holds, that is, audit report lag is significantly and positively related to InvestOpp.

4.4.3 Square root of audit report lag

Consistent with Tanyi et al. (2010), we conduct a sensitivity test using square root of audit report lag as the dependent variable, replacing ARL with SqrtARL in Model (1). The untabulated results are consistent with our 
primary results reported in Table 6 .

\section{Discussion and conclusion}

This paper extends prior research on audit report lag and investment opportunities by investigating whether audit report lag is related to client firms' investment opportunities. Using the sample of 8520 firm-year observations from 2010 to 2012, we find a positive relation between the level of investment opportunities and audit report lag. The results suggest high investment opportunity firms are more likely to have longer audit report delay. Our results are consistent with prior studies. Specifically, the increases in managerial opportunism, complexity and uncertainty associated with investment opportunities, and weakness in internal control lead to an increase in audit risk. The higher audit risk, in turn, induces an expansion in the scope of audit work, and thus longer audit report lags.

The results provide some practical implications. First, long audit report lag leads to the delay in earnings reports, which signals to the market poor financial reporting quality (Knechel \& Payne, 2001). Our results provide useful information to management of HIO firms. The management of HIO firms should find ways to reduce or eliminate audit report delays associated with those opportunities. Second, the findings are also beneficial to external auditors. Specifically, external auditors may put more effort in planning the audit to address the increase in audit risk. Finally, our results may provide useful information to regulators. As audit report lags lead to the delay in earnings releases which ultimately undermines earnings quality, our findings may provide regulators with information about factors causing audit report lags so appropriate and effective legislations can be formulated to alleviate the adverse impact of audit report lags.

Our results suggest several areas for future research. First, future research may explore whether auditor type or auditor industry specialization can mediate the association between investment opportunities and audit report lag. It is expected that Big 4 auditors or industry specialized auditors are more efficient in auditing HIO firms, and thus, reduce audit report delays. Second, subsequent research may examine the influence of corporate governance upon the provision of timely audit reports for firms with high investment opportunities.

\section{Acknowledgements}

The authors would like to thank the editor and the two anonymous reviewers for their helpful comments and suggestions on the earlier version of the paper.

\section{References}

Ashton, R. H., Willingham, J. J., \& Elliott, R. K. (1987). An empirical analysis of audit delay. Journal of Accounting Research, 25(2), 275-292. http://dx.doi.org/10.2307/2491018

Baber, W. R., Janakiraman, S. N., \& Kang, S.H. (1996). Investment opportunities and the structure of executive compensation. Journal of Accounting and Economics, 21(3), 297-381. http://dx.doi.org/10.1016/0165-4101(96)00421-1

Bamber, E. M., Bamber, L. S., \& Schoderbek, M. P. (1993). Audit structure and other determinants of audit report lag: An empirical analysis. Auditing: A Journal of Practice \& Theory, 12(1), 1-23.

Behn, B. K., Searcy, D. L., \& Woodroof, J. B. (2006). A within firm analysis of current and expected future audit lag determinants. Journal of Information Systems, 20(1), 65-86. http://dx.doi.org/10.2308/jis.2006.20.1.65

Belghitar, Y., \& Khan J. (2013). Governance mechanisms, investment opportunity set and SMEs cash holdings. Small Business Economics, 40(1), 59-72. http://dx.doi.org/10.1007/s11187-011-9366-z

Blankley, A. I., Hurtt, D. N., \& MacGregor, J. E. (2014). The relationship between audit report lags and future restatements. Auditing: A Journal of Practice \& Theory, 33(2), 27-57. http://dx.doi.org/10.2308/ajpt-50667

Bonson-Ponte, E., Escobar-Rodriguez, T., \& Borrero-Dominguez, C. (2008). Empirical analysis of delays in the signing of audit reports in Spain. International Journal of Auditing, 12(2), 129-140. http://dx.doi.org/10.1111/j.1099-1123.2008.00375.x

Boudry, W. I., Kallberg, J. G., \& Liu, C. H. (2013). Investment opportunities and share repurchases. Journal of Corporate Finance, 23, 23-38. http://dx.doi.org/10.1016/j.jcorpfin.2013.07.006

Cahan, S. F., Godfrey, J. M., Hamilton, J., \& Jeter, D. C. (2008). Auditor specialization, auditor dominance, and audit fees: The role of investment opportunities. The Accounting Review, 83(6), 1393-1423. http://dx.doi.org/10.2308/accr.2008.83.6.1393

Chen, K. Y., Elder, R. J., \& Hung, S. (2010). The investment opportunity set and earnings management: Evidence from the role of controlling shareholders. Corporate Governance: An International Review, 18(3), 193-211. http://dx.doi.org/10.1111/j.1467-8683.2010.00793.x 
Ettredge, M. L., Li, C., \& Sun, L. (2006). The impact of SOX section 404 internal control quality assessment on audit delay in the SOX Era. Auditing: A Journal of Practice \& Theory, 25(2), 1-23. http://dx.doi.org/10.2308/aud.2006.25.2.1

Gaver, J. J., \& Gaver, K. M. (1993). Additional evidence on the association between the investment opportunity set and corporate financing, dividend, and compensation policies. Journal of Accounting and Economics, 16(1-3), 125-160. http://dx.doi.org/10.1016/0165-4101(93)90007-3

Habib, A., \& Bhuiyan, M. B. U. (2011). Audit firm industry specialization and the audit report lag. Journal of International Accounting, Auditing and Taxation, 20(1), 32-44. http://dx.doi.org/10.1016/j.intaccaudtax.2010.12.004

Jaggi, B., \& Tsui, J. (1999). Determinants of audit report lag: Further evidence from Hong Kong. Accounting and Business Research, 30(1), 17-28. http://dx.doi.org/10.1080/00014788.1999.9728921

Jensen, M. C., \& Meckling, W. H. (1976). Theory of the firm: Managerial behavior, agency costs, and ownership structure. Journal of Financial Economics, 3(4), 305-360. http://dx.doi.org/10.1016/0304-405X(76)90026-X

Kinney, W. R., \& McDaniel, L. S. (1993). Audit delay for firms correcting quarterly earnings. Auditing: A Journal of Practice \& Theory, 12(2), 135-142.

Knechel, W. R., \& Payne, J. L. (2001). Additional evidence on audit report lag. Auditing, 20(1), $137-146$. http://dx.doi.org/10.2308/aud.2001.20.1.137

Kumar, K. R., \& Krishnan, G. V. (2008). The value-relevance of cash flows and accruals: The role of investment opportunities. The Accounting Review, 83(4), 997-1040. http://dx.doi.org/10.2308/accr.2008.83.4.997

Lai, K.W. (2009). Does audit quality matter more for firms with high investment opportunities. Journal of Accounting and Public Policy, 28(1), 33-50. http://dx.doi.org/10.1016/j.jaccpubpol.2008.11.002

Lee, H.Y., Mande, V., \& Son, M. (2009). Do lengthy auditor tenure and the provision of non-audit services by the external auditor reduce audit report lags? International Journal of Auditing, 13(2), 87-104. http://dx.doi.org/10.1111/j.1099-1123.2008.00406.x

Leventis, S., Weetman, P., \& Caramanis, C. (2005). Determinants of audit report lag: Some evidence from the Athens Stock Exchange. International Journal of Auditing, 9(1), 45-58. http://dx.doi.org/10.1111/j.1099-1123.2005.00101.x

McGuire, S. T., Omer, T. C., \& Wilde, J. H. (2014). Investment opportunity sets, operating uncertainty, and capital market pressure: Determinants of investments in tax shelter activities? Journal of the American Taxation Association, 36(1), 1-26. http://dx.doi.org/10.2308/atax-50599

Myers, S. C. (1977). Determinants of corporate borrowing. Journal of Financial Economics, 5(2), $147-175$. http://dx.doi.org/10.1016/0304-405X(77)90015-0

Newton, J. D., \& Ashton, R. H. (1989). The association between audit technology and audit delay. Auditing: A Journal of Practice \& Theory, 8(Supplement), 22-37.

Opler, T., Pinkowitz, L., Stulz, R., \& Williamson, R. (1999). The determinants and implications of corporate cash holdings. Journal of Financial Economics, 52(1), 3-46. http://dx.doi.org/10.1016/S0304-405X(99)00003-3

Schwartz, K. B., \& Soo, B. S. (1996). The association between auditor changes and reporting lags. Contemporary Accounting Research, 13(1), 353-370. http://dx.doi.org/10.1111/j.1911-3846.1996.tb00505.x

Skinner, D. J. (1993). The investment opportunity set and accounting procedure choice. Journal of Accounting and Economics, 16(4), 407-445. http://dx.doi.org/10.1016/0165-4101(93)90034-D

Smith Jr., C. W., \& Watts, R. L. (1992). The investment opportunity set and corporate financing, dividend, and compensation policies. Journal of Financial Economics, 32(3), $263-292$. http://dx.doi.org/10.1016/0304-405X(92)90029-W

Tanyi, P., Raghunandan, K., \& Barua, A. (2010). Audit report lags after voluntary and involuntary auditor changes. Accounting Horizons, 24(4), 671-688. http://dx.doi.org/10.2308/acch.2010.24.4.671

Tsui, J. S. L., Jaggi, B., \& Gul, F. A. (2001). CEO domination, growth opportunities, and their impact on audit fees. Journal of Accounting, Auditing \& Finance, 16(3), 189-208.

Zmijewski, M. (1984). Methodological issues related to the estimation of financial distress prediction models. Journal of Accounting Research, (Supplement), 59-82. http://dx.doi.org/10.2307/2490859 